\title{
The Review of Conflict between the Arabs and the Israelis
}

\author{
Argo Arifin; Taufiq Letri \\ Faculty of Law, University of Novi Sad, Serbia \\ Arifin@gmail.com
}

\begin{abstract}
The Arab-Israeli clash originated from the conflict of the devotion of the two sides to a similar land which is the Palestinian regions settled by both the Arabs and the Jews. This section will attempt to review the advancement of the conflict on the domain by explaining the impacts of Jewish movement, the improvement of Zionist thought, the command period, political groups among the two sides and the wars between the gatherings. Along these lines, the start of the contention and the improvement of the contention will be worried to comprehend the clashing places of the two sides. These positions targets helping the peruse see all the more unmistakably the stop in the harmony procedure.
\end{abstract}

Keyword: Conflict; Arabs; Israelis

\section{Introduction}

Gather expresses that War demonstrated to be an unavoidable strategy for settling questions in the twentieth century. Nevertheless, none of the wars between the Arabs and the Israelis settled the essential clash among Zionists and Palestinians rather exacerbated Israel's security issue and expanded the Palestinians' threatening vibe toward Israel. The majority of the wars between the sides gave essential signs about their points of view concerning the contention. While the Arabs attempted to safeguard their reality in Palestine, the Jews planned for expanding its power over key purposes of the area to ensure the observation of Israel. The wars between the Israelis and the Arabs are analyzed in this investigation inside the structure of the impact of the wars on the Arab-Israeli clash and of the key significance of domain to the sides. Assessing the Israeli and the Arab positions during the wars, this part attempts to present how the regional development of Israel affected the Israeli way to deal with the contention.

During the wars between the Arab world and Israel, each side embraced various ways to deal with the contention. The shared factor of these methodologies is that they kept the sides from concurring on regional trade off. The absence of regional trade off rendered the harmony endeavors cutting-edge flopped in understanding a lasting settlement. Regional trade off appeared to be unimaginable in light of the fact that each side received the reward from keeping the contention and now disavowing this methodology would mean making concessions from their deliberately significant domains (Rapopet, 1989).

Domain, in particular Palestine, had extreme occupation in this contention as far as patriotism as referenced in past sections. The wars between the gatherings show how the regional acquisitions of the two 
sides, particularly Israel, situated them towards the possibility of the continuation of the contention commanding the harmony procedure. Given the extension of Israel and the change of the Arab position in the contention, the wars are contemplated in order to mirror the advancement of the Israeli and the Arab purpose of perspectives while concentrating on the significance of vital domains for the two sides (Gart, 1992).

Conant expresses that the Arabs considered the Israelis as a European pilgrim state and an instrument of other Western states having interests in the Middle East. Nevertheless, Israel considered itself to be a reestablished old Middle Eastern country. Getting support from some Western nations, Israel went for reestablish its old state through vanquishing lands and particularly the terrains of key significance to render its structure prosperous. Notwithstanding Israeli exertion to vanquish more land than it had settled or secure the current ones, the Arabs strived for recover their properties through outfitted clash. The wars until the announcement of Oslo Peace Process exhibited the endeavors of the two sides to delineate the outskirts of their territories in congruity with their national cases. While battling for getting key domains to establish predominance on the other, the two sides saw the upside of the continuation of contention. Particularly Israel received the reward of the continuous clash when it pronounced the reasons of its battle as security reasons (Conant, 1992).

\section{Discussion}

\section{The 1948 War}

The years between the two world wars gave big opportunities to the Jewish people together with their unforgettable suffers. Reaping the benefit of war years and supplementing the weak points of the big powers in economic and military terms, they obtained support from international powers. At least, they made their demands being discussed on the international agenda. They, however, understood that establishing a national home would not solve the Jewish problem. The indigenous people of Palestine, especially Arabs, did not welcome their settlement in enormous numbers in Palestine. The conviction that the Jewish immigration will mean their exile started to take place in minds of Palestinian Arabs (Netanyahu, 2000).

When the World War II started, the Palestinian nationalists led by Haj Amin al-Hussaini sided with Nazi Germany and the Axis powers. This choice meant the loss of an opportunity to reap the benefit from fighting on the Allies' side. By contrast, the Jews seized the opportunity and gained valuable experience with the war that they served it well later.

During the World War II, the Zionist movement continued to gain support for the Jewish control over Palestine. The Biltmore Programme in 1942 of World Zionists Congress in Biltmore Hotel, New York, consolidated the establishment of a future Jewish state. This congress declared that "the word 'homeland' in the Balfour Declaration implied a nation and that a nation meant a state.' As the Nazis continued executed genocide to the Jewish people in Europe, the Zionist movement received tremendous support from the United States that has the largest Jewish community. Meanwhile, the rights of indigenous Arabs were ignored. In the face of the possible influx of the European Jews, the U.S Jews directed the European Jewish refugees into Palestine because they did not want loose their relative equality and status in the U.S. due to negative effect of the mass migrations of the Jews on their positions in the administration. The result of Britain's failure to solve the Palestine problem was the Morrison Grady Plan which was the Britain's final attempt to achieve a settlement. This plan proposed transforming the mandate into a United Nations 
trusteeship and divided Palestine not into separate Jewish and Arab sovereignties, but provinces. Though the Jewish 'province' in this plan was smaller than provided by the proposal of the Peel Commission, the Plan was providing the entry of 100,000 Jewish refugees into Palestine within a year. Consequently, Britain turned the whole matter to the United Nations in 1947 (Brison, 1969).

In the aftermath of the World War II, 75.000 the United Nations adopted Resolution 181 in 1947, which recommended the partition of Palestine into an Arab state (Golan Heights to Syria, West Bank and eastern Jerusalem to Jordan, Gaza Strip to Egypt) and a Jewish state in the remainder, along with the internationalization of Jerusalem. The Palestinians and Arab states rejected partition; the Zionists accepted.

Because of the increase in the Jewish immigration to Palestine between 1945 and 1947, violence between the Jews and the Arabs accelerated. After Britain unilaterally terminated her Mandate over Palestine, on 14 May 1948, a Jewish state, the state of Israel was proclaimed. Immediately, Jews initiated their war of independence that triggered the hatred between the Jews and the Arabs. At the end of 1948 war, Israel has expanded its control over 77\% per cent of Palestine, and thousands of Palestinian Arabs became displaced. By the establishment of a Jewish state, the Zionists accepted nothing less than a state and Palestinian Arabs exerted effort to inhibit the realization of the Zionist desire for a national home. Following the British withdrawal, 1948 war erupted between the state of Israel established in 1948 and the Arab states of Egypt, Iraq, Lebanon, Syria and Transjordan (Sisco, 1976).

At the end of 1948 war, Palestinian refugee problem emerged. While the refugees were expecting to return to their homes, Israel refused to admit more than a small number and denied paying compensation for the ex-properties of the refugees. Therefore, Israel seemed to deny the indigenous rights of ex-habitants of Palestine. How the Jews had claims over Palestine, the displaced Arabs had also claims over the land. However, the Jews did not tend to accept these claims after their complete settlement within a state. Moreover, Israel expected the Arab states to absorb the refugees. The United Nations Relief and Works Agency (UNRWA) gave the human and financial aid to the refugees in 1950.

In addition, the problems of Palestinian were seen as the only refugee problem between 1949 and 1964 as if they had not been indigenous residents of Palestine before the 1948 war. Though the self-identity was strengthened in the refugee camps among the Palestinians, they had no political institution of their own to announce their right to return and have their own state. After the dissolution of the Husayni government at the end of 1948, some notables like al- Haj Amin was urged to go exile. During this period, Palestinian political thinking was divided between the ones struggling alone for an Arab Palestine, and the others supporting a united Arab world.

Following the 1948 war, the positions of both sides were radically different. Their common search for national identity and self-determination resulted in diversified ends. The Jews achieved statehood through the establishment of Israel. The self-determination right of the Palestinians was denied and they were forced to exile. In the subsequent years, these two divergent conditions of both sides would determine their rapprochements to the transformation of the conflict. As the Jews formulated their statehood, the Palestinian Arabs started to regulate their late national movement (Tibi, 1999).

\section{The 1956 Suez / Sinai War}

The fear of Israel against the Nasser's growing influence throughout the Arab world and the spread of militant Pan-Arabism were solidified in Israel's reaction to the Nasser's nationalization of the Suez Canal in 1956. In order to prosper the worsening Israeli economy suffered from heavy military expenditures, Israel 
needed to benefit from the commerce passing through the Suez Canal. Economic boycott and blockade imposed by Nasser, moreover, the closure of the Suez Canal put Israel in a hard situation.

In the face of the Western powers rejection to sell Nasser military equipment in order to keep a balance of power in the Middle East, Nasser refused to participate in the containment policy against the Soviet Union. After Nasser received the refusal of the West to give financial assistance to construction of the Aswan High Dam on the Nile River, he nationalized the Suez Canal and banned the access of Israeli ships through the Canal. Taking the military support from the Soviet Union, Nasser broke the Western arms monopoly in the Middle East and deviated from the policy of Western powers against the Soviet Union. His arising reputation among the other Arab states, the West a Soviet satellite considered Egypt as a regional power. Taking the support of the Soviet Union behind, Nasser inclined to take the revenge of the defeat in 1948 and the situation of the Arab refugees promoted the hostility to Israel in the Arab states refusing to negotiate with Israel (Rich, 1985).

The developments before the outbreak of the 1956 Suez/Sinai War demonstrated the competition of the sides to dominate the strategic land in order to consolidate their existence on the debated territories.

Because of the war, Egypt gained reputation among the Arab states with its defiance to the West in spite of its military defeat. Israel agreed to leave Egypt if UNEF guaranteed freedom of navigation in the Gulf Aqaba. British and French forces withdrew by the end of 1956. Israel attained free passage through the Gulf Aqaba. Egypt remained in total control of the Suez Canal. In short, both sides noticed that Western support granted them stronger standpoint in the conflict. In particular, the rivalry between the U.S and the Soviet Union, served to the interests of both sides concerning the consolidation of their power on the strategic points that would contribute to the development of the Israeli state and the Palestinian Arab national movement.

\section{The June 1967 Six Day War}

With the foundation of the PLO under the auspices of Nasser and Nasser's initiatives such as the 1964 Cairo summit to overcome inter-Arab rifts and convene all the Arab states around the goal of creating a unity against Israel, the tensions between Israel and the Arab states led to a new war.

The attempt of Israel to use Lake Tiberias, the demilitarized zone between Israel and Syria, to store water (Israel's Jordan River diversion project) was denied by the Arabs at the 1964 Cairo summit. Moreover, the initiatives launched by Syria and Lebanon to work on the project, stimulated the Israeli aggression. Moreover, Egypt's military pacts with Syria in 1966 and Jordan in 1967 intensified the Israel's feeling of encirclement. This feeling stemmed from the rise of Egypt among the Arab states and the support of the U.S to the neighbors of Israel threatening (Brison, 1969).

During the decade following the Suez / Sinai War, the conditions in the Middle East changed deeply. First, revolutionary Egypt gained major impact on the political unrest, civil wars and revolutions in the other Arab states such as Jordan, Saudi Arabia, Lebanon and Iraq (1958). Second, both the Soviet Union and the U.S led escalating armament race. The United States supplied arms to the conservative regimes in Iran and SaudiArabia against the Soviet Union, the major supplier of massive weapons to Iraq and Syria (Jabotinsky, 1937).

Yet, Israel intended to turn this challenge into an advantage. By triggering Nasser's hostility, Israel tried to render its aggressive attitude legitimate. The 1967 war created a justification to Israel for attack and 
realize its goal of increasing its territory and eliminating its difficult adversary; Egypt under the leadership of Nasser.

At the end of the 1967 June War, Israel had overturned the balance of power in the Middle East. Its principal Arab foes were militarily crushed and any hope of destroying Israel by force became out of question. Israel enhanced its control over Gaza, all of Jerusalem and the West Bank and the Golan Heights.

After the June war, territorial Zionism came to the threshold in the Israeli politics. Though some parties such as the Arab Communists and the small left wing factions were willing to make territorial concessions in return for peace with the Arab state, Israel seemed to refrain from ceding the strategic territories that allowed the passage of Egypt's Sinai petroleum and the influx of tourists to Jerusalem.

The 1967 defeat was as disastrous as the 1948 war for the Arab world. Egypt, Jordan and Lebanon experienced an enormous economic damage as well as collapse of Arab morale and self-confidence. Moreover, the war created another group of Palestinian refugees.

The causes of the Arabs' failure in the 1967 war actually clarified the general lacks in the Arab attitude against Israel. Problems such as false calculation, wrong intelligence and inadequate communications restricted the Arabs' activities.

The Arabs' refusal of admitting the principle of compromise in the diplomatic field always facilitated the position of Israel. This approach stemmed from the lack of single entity. The Arab side had no unified political or military structure. Furthermore, conflicting decisions and intentions always damaged the so-called unity of Arabs. Lastly, Israel ignoring all historical perspectives generally focused on only maintaining its status quo.

The Arab-Israeli conflict emerged as an instrument for the both sides' administrations to hide their incapability of constituting stability for their people. Both sides were able to achieve unity in spite of their internal rivalries by means of uniting around the goal of defeating the other side. In this sense, the ArabIsraeli conflict emerged as a tool for leaving internal clashes aside and focusing on main national aspirations. Intifada and the Six Day War proved to be important turning points in the developments of both national movements in spite of their grievous outcomes.

The 1967 war seemed a crucial step for Israel in the direction of its ancient aim of establishing 'Greater Israel'. However, its occupation of such a wide range territories had also negative ramifications. It obtained the territories whose control was desired by three Arab states; Egypt, Syria and Jordan. This meant that Israel would able to strengthen its claim that Palestinians had threatened its security so that it was obliged to pursue a defensive foreign policy. By the inclusion of these three states into the issue, Israel's perception of danger was widened. The more it demanded to conquer land, the more it escalated its attacks in the pretext of ensuring its security. Though Israel obtained the control of over a million Arabs in the occupied territories, the Arab side already rejected to have direct negotiations with Israel (Hamami, 1994).

Therefore, the June war aggravated the old problems such as the Palestinian refugees and created new ones such as the problems of Suez Canal and Jerusalem. The vicious cycle appeared between the Arabs and the Israelis. Aiming at eradicating the encirclement by the Arabs and expanding as soon as possible to strengthen their state, the Israelis exerted effort at the expense of the non-recognition of the UN Resolutions. The territories acquired by Israel such as Gaza, West Bank and the Golan Heights would become the focus point of the conflict. Israel's possession of these territories rendered Israel economically and strategically powerful. 
For the Israelis, control over these territories solidified its being as a state through the legitimacy of the existence of this state which is debatable. The more Israel conquered the most valuable points of Palestine the more its survival was guaranteed. The only challenge, which is the spread of the influence of the PLO to the other countries in the Middle East, should have been undermined in order to secure its new borders. Israel attained more powerful reason to continue to exist in Palestine, which is security of its borders, than the myth of 'Promised Land'. In this vain, the 1973 October War and the 1082 War served to the consolidation of the Israeli borders and Israel's resistance to the cross-border attacks of the PLO. Israel used these attacks for the legitimization of its non- recognition of withdrawing to pre-1967 borders. Therefore, the continuation of the conflict strengthened the settlement of the Israelis in Gaza, West Bank and the Golan Heights (Cohen, 2005).

\section{The 1973 October War}

Throughout the early 1970s, the major focus point of Egypt, Jordan and Syria was persuading Israel to return to the 1949 armistice lines. Nevertheless, Israel declared that this was impossible for itself because of its security concerns. After Nasser's death, his successor Anwar Sadat tried to regain respect at home as well as before the world community. By restoring diplomatic relations with the U.S, he tried to have peace with Israel based on Resolution 242. In the face of Israel's consistent resistance to withdraw to pre-1967 borders, Sadat started to prepare for a war against Israel with Syrian president Hafez al-Assad. Despite of the moderate approach of Sadat to the conflict, the war appeared to be inevitable due to the lack of confidence between both sides.

The most severe repercussion of the October War of 1973 was the OPEC's (Organization of Petroleum Exporting Countries) petroleum embargo and the rise in the prices of oil. This attitude of the Arab states displayed that the high level support of the Western countries to Israel would have significant economic cost. Petroleum appeared as an important tool that was to redress the power imbalance between the Arab states and the West. This resulted in a change in the relationship between the Arab states and industrialized powers such as the U.S (Fox, 2004).

When the ceasefire was ordered on October 22, 1973, the United Nations Security Council passed the Resolution 338 that is a companion to 242 as the basis for future peace proposals. It called for immediate termination of all military activity, implementation of Resolution 242 and the start of negotiations aimed at establishing a just and durable peace in the Middle East. As a result of Henry Kissenger's 'step by step' approach to the conflict, first bilateral accord could be signed between Israel and Egypt since the 1949 armistice. Furthermore, the U.S persuaded Egypt to reduce its troops east of the Canal, to establish a buffer zone in Sinai patrolled by a U.N. Disengagement Observer Force (UNDOF) and to reopen the canal to nonIsraeli shipping and Israel to withdraw its forces the Sinai to some 20 miles east of the Suez Canal. A buffer zone patrolled by UNDOF was also established between Israeli and Syrian forces in the Golan Heights and President Assad agreed to prevent Palestinian guerillas from using Syria as base for attacks on Israel.

These disengagements of Egypt and Syria against Israel renewed the diplomatic relations between the U.S and, Syria and Egypt. Egypt had the crucial role in the development of this diplomatic climax. Egypt's 1973 military accomplishments allowed Kissenger's shuttle diplomacy and Sadat to initiate peace negotiations in 1977. Despite Egypt bettered its relations with the West and Israel, its relations with Syria deteriorated.48. Assad feared that Egypt's relative compromise with Israel would undermine his efforts to regain the Golan. For this reason, he did not participate in further peacemaking efforts of Egypt and joined anti-Israel Rejectionist Front including Iraq, Algeria, Libya, South Yemen and the PLO. 
Following the October war, Sadat initiated his new peace efforts. Expelling his Russian advisors from Egypt in 1972, Sadat opted for having direct negotiations with Israel. In this sense, his demand for address the Knesset and discuss peace surprised Israel, the Arab states and the United States. Sadat's visit to Jerusalem in 1977 broke the psychological barrier preventing the Arab side from discussing the issue face to face and implied the possibility of Egypt's recognition of Israel. This standpoint of Egypt concluded with agreement to begin peace negotiations but also urged the Arab states to exclude Egypt that was suspended from membership in the Arab League (Bickerton \& Klausner, 2002).

The Camp David Talks between Israel and Egypt culminated in two accords "Framework for Peace in the Middle East" and "Framework for the Conclusion of a Peace Treaty between Egypt and Israel." The Egyptian Peace Treaty was signed in Washington in 1979. The peace treaty led to the opposition of Left parties and Islamic fundamentalists and the alienation of pan-Arabists as a result of Egypt's isolation from the rest of the Arab world. For Israel, the October war raised the doubts about Israel's invincibility and undermined the belief that no territorial concessions were needed. The war consolidated Israel's dependence on its relations with the U.S. The 1973 war had also tremendous effect in the political life of Israel. The Likud opposing any territorial concession for peace as a result of 1977 elections replaced the Labor party supporting the idea of peace in exchange of territory. The prime minister, Likud leader Menachem Begin, with its coalition members favoring "Greater Israel" called for annexation of the territories.

\section{The Effects of Intifada on Arab Nationalism}

Intifada with its origins within the tension-fledged territories emerged as spontaneous and politically inspired uprising. These well-underground groups controlled organized civil resistance movement. The principle underground leadership group was the Unified National Command (UNC), with representatives from Fatah, the Popular Front for the Liberation of Palestine (PFLP), the Democratic Front for the Liberation of Palestine (DFLP) and the Palestine Communist Party (PCP). The others were Hamas and Islamic Jihad that played an active role in Intifada. They called for the destruction of Israel and totally opposed to have any negotiations with Israel with its widespread character and long duration, Intifada expressed the Palestinians' suffer for years to the world. For the first time, different local groups including Muslim radicals, communists and secular nationalists integrated for the common national cause.

Moreover, Yapp states that the Intifada was a serious blow to Israel's attempt to argue that Palestinian opposition was merely the result of PLO terrorism against those accepted Israeli rule. Intifada, namely the shaking-off, broke out in 1987 as a widespread resistance encompassing the entire population. The outbreak of Intifada resulted from the development of political consciousness among the 'insiders' living in the occupied territories. Nassar states that the importance of the occupied territories for the Palestinian national movement is the admiration and respect accorded to the resistance there. The West Bank and Gaza constituted an important arena for the development of the political struggle and a strong social base.

The development of political consciousness began with the Palestinian reaction to the Jewish immigration and it was crystallized with the founding of the Palestinian National Liberation Movement (Fatah) in 1957-58. Furthermore, the PLO enforced the political consciousness with the consolidation of an independent Palestinian institutional infrastructure. These political organizations led to the political mobilization of the Palestinians inside or outside the occupied territories. The 1967 war had the most triggering effect on the flowering of the Palestinian resistance. After the 1967 war, the Palestinians could be 
mobilized towards the same end. The political factions emerged in the period until 1967 stood near the PLO in Intifada though they conducted divergent acts in the following phases of Intifada.

Fatah, the PFLP, the DFLP, the Palestinian Communist Party and the Islamic movement gathered under the auspices of United Leadership to control the uprising. In the first sight, Intifada proved to be a significant event that united all Palestinian factions in spite of their different approaches. In Intifada all sections of the Arab community in Palestine participated in the uprising. Palestinian Arabs were unified, as it had never been before. In the 1936-39 Arab revolts failed because of traditional clan rivalries. Internecine struggle among Palestinian factions was repressed in Intifada. However, these different positions did not last and revealed at the end of Intifada. Especially, Islamic fundamentalists rejected the PLO's diplomatic struggle. Before the proclamation of the state of Palestine in 1988, these diversified positions reduced the effect of Intifada. It displayed to the international community that the grievous situation of the Palestinians and they were not the aggressors as Israel asserted (Mendelsohn, 1993).

Despite of the divided approaches, Palestinians experienced great psychological change during Intifada. Inhabitants of Palestine decided to conduct their own state of affairs rather than waiting no longer for foreign assistance. This self-reliance and solidarity among Palestinians galvanized national consciousness in Palestinian society.

Moreover, the Palestinians noticed that they should count on only their own strength rather than the outside world. Intifada demonstrated the Palestinians their ability to stand robust against Israel in their fight against injustice.

Against the Palestinian resistance, Israel displayed a disproportionate reaction that will be traditionalized by Israel in its further reactions. This feature of the Israeli reaction emanates from the fear of the Israelis that even one person is of the vital importance for its survival on the Palestinian territories. Israel, as a state established as a result of systematic immigrations, occupied the other's territories and displaced them with a view to creating and maintaining a Jewish majority (Sachar, 1998).

While the characteristic of the Israeli reaction was disturbing Israel's image, Intifada made the international community recognize the Palestinians as a party of the conflict and their right to defend themselves against the repressive Israeli occupation. This cordial approach towards the Palestinians encouraged the PLO to start a diplomatic offensive.

The Palestinian problem was not a sole refugee problem anymore as the Israelis had contended until Intifada. The PLO started to stand on a historical turning point in the PLO's political direction concerning the recognition of Israel's right to exist and its opinion for a two state solution. Nonetheless, the inappropriate reaction of Israel, the divisions among the Palestinians and their terrorist attacks shadowing the soul of Intifada transformed Intifada from an unpopular uprising into a veritable urban guerilla war.

At the end of the abovementioned wars, Israel conquered very strategic points which would be conceived as inalienable parts of the Israeli state. Territorial compromise on these points such as Gaza, West Bank and the Golan Heights meant to share the prosperity of the state of Israel that is unacceptable. Moreover, its control over Jerusalem was the main possession of Israel which gathers all the Israeli Jews together and maintains the support of the others around the world for their existence of Israel. Thus, withdrawal from these territories was meaningless for the Israelis. To cover its illegitimate existence and consolidate its future in the Middle East, these territories are the main insurance for the Israelis. The only way to keep on standing the Palestinian reactions is to display the Palestinians as aggressors. In this concern, Israel is destined to continue to conflict (Anderson, 2006). 
On the other side, the loss of only valuable territories to Israel always rendered the Palestinians weak in economic terms. Moreover, political separations among the Arab states deprived the PLO of the support of the Arab world. The only way to stand strong against Israel was to attack Israel. Though these attacks displayed the PLO as aggressors until Intifada, the continuation of the conflict disguised their economic and political weakness.

Within these considerations in mind, the above-mentioned wars determined the policy of both sides in the following years of peace efforts. As a result of these wars, territory emerged as not only an instrument on which they establish their nationalisms but also as a tool for promoting their resistance. A chance of territorial compromise was abolished during these wars. These territories include vital elements such as water, sacred places for two religions. The one who possess these territories would guarantee his existence. Therefore, the Palestinians and the Israelis adopted the continuation of conflict in order to dominate these territories. While telling a summarized history of the wars until the beginning of the peace process, the study will observe the rapprochement of the parties to the conflict and will try to demonstrate whether their attitudes of are conciliatory or not. In order to prove the decisive commitment to the conflict of Palestinians and the Israelis, the study will scrutinize the deficiencies of the peace process that urged the communities to adopt the continuation of conflict. Underlining the main issues that should be settled for achieving a lasting peace, the importance of territorial compromise is reflected in the study. Lastly, the thesis argues that territorial compromise could not be obtained because both sides espoused the continuation of the conflict with a view to perpetuating their national claims to Palestinian territories.

The establishment of the State of Israel in 1948 constituted the turning point in the conflict. It represented the beginning point of incompatible policies between the sides. The establishment of their state by the Jews regardless of the rights of Palestinian Arabs urged Arabs toreact in the most feasible way: attack on Israel in order to get back their right to exist in Palestine. For this reason, the Israelis always considered the Arabs as a threat to their secure environment in which they could maintain their survival that had also fallen in danger due to the Nazi genocide during the World War II. The Israelis were in urgent need of reinforcing the presence of their state, which was compulsory to their opinion. However, the realization of this urgent need was at stake. The Jews obliged to exile from Europe to another land had constituted a state by rendering the indigenous Arabs displaced. The positions of each side encompassed the exclusion of the other and acceleration of the hatred in search for gaining legitimacy for their existence (Chen, 1954).

The wars waged between the sides between 1948 and 1967 proved this idea. As Israel was seeking to protect security of its borders, the Arabs of Palestine were striving to obtain their rights to return. During this array of wars, the international conjuncture also affected the development of the conflict. After the foundation of the PLO as the first organized national institution of the Palestinian Arabs and their oil embargo in 1973, international powers, especially the U.S, started to endeavor for the construction of peace in the region as leaving aside their concerns inherited from the Cold War years.

During the wars, each side, particularly Israel, reaped the benefit from the conflict. The territorial achievements of Israel were valuable. In order to maintain these acquisitions such as the control of Gaza Strip, West Bank and Golan Heights, Israel put forward her security concerns as the pretext to attack the Palestinian Arabs. Against the attacks of Palestinians, she displayed the Palestinian Arabs as aggressors until Intifada to cover her disproportionate reactions to the Palestinians. Israel used the Palestinian attacks towards itself to legitimate its policy to refuse to withdraw from the occupied territories with bringing forward her security concerns. With the outbreak of Intifada, the Palestinian Arabs received support from the international community for the first time. The recognition of the Palestinian Arabs' right to exist is firstly and ironically recognized through stone throwing instead of negotiations. The national cause of the Palestinian Arabs gained legitimacy because of conflict.Therefore, both sides viewed that the continuation 
of the conflict can be instrument in order to maintain their existence on the Palestinian territories (Hastings, 1998).

Following the wars between the sides, peace arrangements failed in putting forward a lasting settlement to the conflict. Peace negotiations were ceased by violence at every turn. Given the peace initiatives until 2006, each peace effort appeared unsuccessful because of ongoing violent attacks of one side towards the other. This could be explained with the interests of both sides in the continuation of conflict. Otherwise, each side should have agreed on territorial compromise urgently needed to achieve a lasting peace.

However, territorial compromise would mean renounce all national commitments to the Palestinian territory for each side. It is obvious that none of them would like to share territory. They may agree on living in coexistence in the future. Yet, it seems impossible to share the Palestinian territory as long as Israel insisted on refusing to withdraw from the occupied territories of which the control is strategically important for Israel and HAMAS recognize the existence of Israel in Palestine. The developments from 1979 Camp David to 2006 attested the accuracy of these ideas.

\section{Conclusion}

The most imperative component in the Arab-Israeli clash is the national connection to Palestinian domain of the Jews spread around strongly around Europe and the Arabs that scattered in Arab landmass. The primary explanation of the contention is past the doubt between the Jews and the Arabs that have clashed for quite a long time. The primary explanation of the steady insoluble nature of the contention is the request of the two sides not to make any concession from their regional goals on Palestine. The determinant frame of mind of the Arabs and the Jews originated from the method for their national development.

Both the Arabs and the Jews developed their patriotism so as to demonstrate that they are the genuine and antiquated owners of Palestine. For the Jews, Palestine is their 'guaranteed land'. At the point when Zionism is expounded, it tends to be comprehended that Zionists received the reward of this strict confidence to take care of the Jewish issue by building up a Jewish state in Palestine. For the Arabs, Palestine is the arrive on which Arab greater part had been enduring the Arab personality since old occasions. The Arabs battle that the Jews had come, settled and attempted to kill the Arab presence in Palestine. For the Jews, Palestine is the country for the Jews who do not want to go back to the Diaspora days. For the Arabs, Palestine is an Arab land that was vanquished by Zionists.

The Arab patriotism and Zionism developed patriotism based on these methodologies in order to reject the other and guarantee the authority over Palestinian domain. This examination has attempted to show the development of these methodologies by mirroring the both national developments and the profound attached national connection to Palestinian domain. This assessment exhibited that the connection of the Jews and the Arabs to Palestine is unbreakable in light of the fact that domain establishes the premise of the Jewish and Arab patriotism. This theory contends that the clashing national connection of theArabs and the Jews to region had likewise decided the advancement of the contention in time.

The examination attempts to mirror that Arab patriots and Zionists did not have equivalent positions. These positions broadened the doubt between the sides of the contention originated from creating national developments on a similar region. Nevertheless, the quickening threatening vibe was not the sole result of continuous conflict over Palestine. Zionist patriot development showed up as a sorted out and qualified 
current equipped for drawing worldwide help of global network through its relations with Britain. Conversely, Palestinian Arab patriot development was separated, confused and denied of the capacity to express its belief system in the universal field.

\section{References}

Anderson, B. (2006). Imagined Communities: Reflections on the Origin and Spread of Nationalism. London: Verso.

Bickerton, I. J., \& Klausner, C. L. (2002). Arab-Israeli C onflict (Third edit; S. Yaron \& O. Falk, eds.). New Jersey.

Brison, D. (1969). The Origins of the Crimean War (Gooch, ed.). Lexington, Massachusetts: D.C. Heath \& Co.

Chen, B. (1954). The Chief Rabbinate in Israel. Jerusalem: Ministry of Religious Affairs.

Cohen, S. (2005). Intractability and the Israeli-Palestinian conflict. Washington D.C: United State Institute of Peace.

Conant, M. A. (1992). Middle East stability A view from the USA.

Fox, J. (2004). The Rise of Religious Nationalism and Conflict: Ethnic Conflict and Revolutionary Wars, 1945-2001. Journal of Peace Research, 41(6), 715-731. https://doi.org/10.1177/0022343304047434

Gart, M. J. (1992). The warrior nation in search of peace.

Hamami, J. (1994). al-Islamiyyun wal-Marhala al-Qadima. Nablus: Markaz al-Buhuth wal- Dirasat alFilastiniyya.

Hastings, A. (1998). The Construction of Nationhood. Cambridge: Cambridge University Press.

Jabotinsky, V. (1937). Evidence Submitted to the Palestine Royal Commission (pamphlet). London.

Mendelsohn, E. (1993). On Modern Jewish Politics. New York: Oxford University Press.

Netanyahu, B. (2000). A Durable Peace. Israel and Its Place Among the Nations. New York: First Warner Books Printing.

Rapopet, A. (1989). The Origins of Violence: Approaches to the Study of Conflicttle. New York: Paragon House.

Rich, N. (1985). Why the Crimean War? A Cautionary Tale. Hanover: University Press of New England.

Sachar, H. (1998). A History of Israel from the Rise of Zionism to Our Time. New York: Alfred A. Knopf. 
Sisco, J. J. (1976). America in the Middle East War and Peace in the Middle East : A Critique ofAmerican Policy. By Avi Shlaim. Review Essays In F? -ienh in Deed, Dan Raviv, a CBS news correspondent , and Yossi. 286-290.

Tibi, B. (1999). Conflict and War in the Middle East: From Interstate War to New Security. New York: St. Martin's Press.

\section{Copyrights}

Copyright for this article is retained by the author(s), with first publication rights granted to the journal.

This is an open-access article distributed under the terms and conditions of the Creative Commons Attribution license (http://creativecommons.org/licenses/by/4.0/). 